\title{
Desafios e possibilidades da inclusão escolar de crianças com a Síndrome Congênita do Vírus Zika: o olhar docente
}

\author{
Challenges and possibilities of school inclusion of children with Zika Virus \\ Congenital Syndrome: the teacher's view
}

\section{Desafíos y posibilidades de la inclusión escolar de niños con el Síndrome Congénita del Virus Zika: la mirada docente}

\author{
* Gessivânia de Moura Batista \\ Doutoranda pela Universidade Federal de Pernambuco (UFPE), Recife, Pernambuco, Brasil. \\ gessivaniamoura@hotmail.com

\section{** Ana Karina Moutinho} \\ Professora doutora na Universidade Federal de Pernambuco (UFPE), Recife, Pernambuco, Brasil. \\ karinamoutinho@gmail.com
}

Recebido em 13 de janeiro de 2019

Aprovado em 01 de maio de 2019

Publicado em 05 de junho de 2019

\section{RESUMO}

A Síndrome Congênita do Vírus Zika (SCVZ) acometeu, entre 2015 e 2018, 3.226 crianças em todo Brasil. Estas crianças nasceram com um padrão de múltiplas deficiências, incluindo déficits visuais, auditivos, motores e cognitivos. Passados três anos desde o início da epidemia, acentua-se a necessidade de discutir sobre sua inclusão escolar, uma vez que, em virtude dos agravos ocasionados pela Síndrome, o suporte social e educacional especializado é imprescindível. O objetivo do presente estudo é apresentar os resultados de uma investigação acerca dos desafios e possibilidades da docência a crianças com a SCVZ, sob a ótica de duas professoras atuantes na Educação Infantil da rede pública de ensino de Pernambuco. Utilizamos como instrumento de investigação um total de cinco entrevistas semiestruturadas. Os resultados obtidos neste estudo apontam que os principais fatores que dificultam a inclusão de crianças com a SCVZ, reconhecidos pelas docentes são: as más condições na estrutura física da escola e a falta de conhecimento das especificidades da Síndrome. Porém, ao longo da pesquisa, quando continuavam a prospectar sobre o futuro, as profissionais consideram que diante da situação de lecionar para crianças com a SCVZ, promoveriam situações de inclusão, a partir do uso de materiais concretos, coloridos e de texturas. Diante dos resultados obtidos, concluímos que as professoras imaginam desafios, e até possibilidades para que docência a crianças com a SCVZ seja exitosa, porém, por falta de preparo técnico sobre a Síndrome, não conseguem traçar possibilidades de ação mais direcionadas a estimulação multissensorial cognitiva, 
motora e socioafetiva desses discentes.

Palavras-chave: Formação de professores; Inclusão; Síndrome Congênita do Vírus Zika.

\section{ABSTRACT}

The Congenital Syndrome of the Zika Virus (SCVZ) rushed in, between 2015 and 2018, 3.226 children throughout Brazil. These children were born with a pattern of multiple disabilities, including visual, auditory, motor, and cognitive deficits. Three years have passed since the beginning of the epidemic, and there is a need to discuss their inclusion in school, since, due to the problems caused by the Syndrome, specialized social and educational support is essential. The objective of the present study is to present the results of an investigation about the challenges and possibilities of teaching to children with SCVZ, from the perspective of two teachers working in Early Childhood Education in the public school system of Pernambuco. We used as a research instrument a total of five semi-structured interviews. The results obtained in this study indicate that the main factors that hinder the inclusion of children with SCVZ, recognized by teachers are: poor conditions in the physical structure of the school; and the lack of knowledge of the specificities of the Syndrome. However, during the research, when they continued to prospect about the future, the professionals consider that in view of the situation of teaching for children with SCVZ, they would promote situations of inclusion, from the use of concrete, colored materials and textures. Faced with the results obtained, we conclude that the teachers imagine challenges, and even possibilities for teaching children to SCVZ to be successful, but due to a lack of technical preparation on the Syndrome, they can not trace possibilities of action more directed to multisensory, cognitive, motor and socio-affective of these students...

Keywords: Teacher training; Inclusion; Congenital Zika Virus Syndrome.

\section{RESUMEN}

El Síndrome Congénito del Virus Zika (SCVZ), acomete, entre 2015 y 2018, 3.226 niños en todo Brasil. Estos niños, nacieron con un patrón de múltiples deficiencias, incluyendo déficits visuales, auditivos, motores y cognitivos. Después de tres años desde el inicio de la epidemia, se acentúa la necesidad de discutir sobre su inclusión escolar, ya que, en virtud de los agravios ocasionados por el Síndrome, el soporte social y educativo especializado es imprescindible. El objetivo del presente estudio es presentar los resultados de una investigación acerca de los desafíos y posibilidades de la docencia a los niños con la SCVZ, bajo la óptica de dos profesoras actuantes en la Educación Infantil de la red pública de enseñanza de Pernambuco. Utilizamos como instrumento de investigación un total de cinco entrevistas semiestructuradas. Los resultados obtenidos en este estudio apuntan que los principales factores que dificultan la inclusión de niños con la SCVZ, reconocidos por las docentes son: las malas condiciones en la estructura física de la escuela; y la falta de conocimiento de las especificidades del Síndrome. Sin embargo, a lo largo de la investigación, cuando continuaban prospectando sobre el futuro, las profesionales consideran que ante la situación de enseñar para niños con la SCVZ, promoverían situaciones de inclusión, a partir del uso de materiales concretos, coloridos y de texturas. 
En cuanto a los resultados obtenidos, concluimos que las profesoras imaginan desafíos, e incluso posibilidades para que docencia a niños con la SCVZ sea exitosa, pero por falta de preparación técnica sobre el Síndrome, no consiguen trazar posibilidades de acción más dirigidas a la estimulación multisensorial, cognitiva, y en el caso de las mujeres..

Palabras clave: Formación de profesores; la inclusión; Síndrome Congénito del Virus Zika.

\section{Introdução}

No ano de 2015 os profissionais da saúde começaram a reportar simultaneamente um aumento no nascimento de crianças com microcefalia no Nordeste e, posteriormente, nas demais regiões do Brasil. Tal aumento foi de 400\% em relação ao ano de 2014 (BRASIL, 2017), o que gerou uma mobilização entre médicos e pesquisadores do Brasil e do exterior com objetivo de descobrir o que poderia estar ocasionando essa má formação congênita. A partir de investigações, descobriu-se a Síndrome Congênita do Vírus Zika (SCVZ), onde a infecção pelo vírus Zika - essa transmitida pelo Aedes Aegypti durante a gestação expunha o bebê a um quadro infeccioso capaz de causar um padrão de múltiplas deficiências, incluindo deficiência visual, auditiva, motora, cognitiva, crises epiléticas, distúrbios de deglutição, hipertonia e hiperreflexia (EICKMANN, 2016).

O caráter inédito dessa síndrome no Brasil e no mundo gerou um impacto tanto nas famílias, como nos âmbitos da saúde, políticas públicas e educação. Um desafio evidente é a necessidade de encontrar formas de assistir uma geração cujo prognóstico de desenvolvimento ainda é desconhecido. Programas de estimulação precoce foram implantados em caráter emergencial, porém, passados três anos desde o início da epidemia, a preocupação começa a voltar-se para o processo de inclusão escolar dessas crianças. Sabendo-se que, entre 2015 e 2018 há 3.226 casos confirmados da SCVZ em todo Brasil (BRASIL, 2018a), torna-se premente discutir acerca do processo de inclusão escolar desse público, que demandará um suporte especializado.

De acordo com Villachan-Lyra e Almeida (2018), a inclusão de crianças com a SCVZ constitui um desafio, porque é preciso adequações na infraestrutura das escolas, de modo que se tornem acessíveis a estas crianças; entretanto, como veremos no presente estudo, a reformulação estrutural de algumas escolas é urgente para o/a usuário/a e trabalhador/a da educação. Há necessidade ainda de um investimento no preparo técnico dos profissionais para que esses possam ter conhecimentos específicos sobre o quadro clínico 
da Síndrome, e sejam capazes de criar estratégias didáticas que atendam às demandas desse público.

Mediante os desafios acerca da inclusão escolar de alunos com deficiência, e considerando que as primeiras crianças nascidas com a SCVZ estarão em 2019 com 04 anos, em idade de ingressar na pré-escola, traçamos como objetivo geral desta pesquisa investigar o que professoras, atuantes na Educação Infantil da rede pública de ensino, imaginam acerca da docência a crianças com a SCVZ.

\section{Aspectos sintomatológicos da Síndrome Congênita do Vírus Zika}

O crescente nascimento de crianças com microcefalia em Pernambuco e, posteriormente, em outros estados do Brasil no ano de 2015, indicava o início de uma epidemia que acometeu, até o ano de 2018, pelo menos 3.226 crianças em todo território Nacional (BRASIL, 2018a). O Vírus da Zika, esse transmitido pelo mosquito Aedes Aegypti, não apresenta grandes danos ao organismo humano, e se manifesta com sintomas de febre, dor de cabeça e nas articulações que tendem a desaparecer em uma semana (LUZ; SANTOS; VIEIRA, 2015). Porém, ao infectar uma gestante, o vírus é capaz de causar sérios danos ao bebê, que em período de formação, tem o Sistema Nervoso Central gravemente afetado. A infecção causa calcificações intracranianas e consequentes anormalidades cerebrais, que refletem em um padrão de múltiplas deficiências, incluindo alterações oculares, auditivas, cognitivas e motoras (RIBEIRO et al., 2017).

A microcefalia não é um agravo novo e não é uma doença em si, mas um sinal de destruição ou déficit do crescimento cerebral, que por ser de etiologia complexa e multifatorial, pode estar relacionada a fatores genéticos e cromossômicos, bem como a exposições ambientais da gestante ao consumo de álcool, drogas, contato com substâncias químicas ou radiação ionizante. Pode estar atrelada ainda a distúrbios metabólicos e processos infecciosos, como rubéola, herpes e sífilis (VARGAS et al., 2016).

Como o vírus da Zika causa um processo infecioso, pelo menos $91 \%$ das crianças nascidas com a SCVZ apresentam microcefalia (WHEELER, 2018). Porém, conforme as investigações avançaram, foi possível constatar que "a microcefalia não é a única forma de manifestação de alterações neurológicas decorrentes da infecção pelo vírus Zika" (VILLACHAN-LYRA; ALMEIDA, 2018, p. 81), já que algumas crianças nasciam com perímetro cefálico dentro dos parâmetros normais, e apresentavam comprometimentos neurológicos característicos da SCVZ. 
Devido ao amplo espectro da Síndrome, os graus de comprometimentos tendem a variar, entretanto, quanto mais precoce acontece a infecção, maiores são os danos ao Sistema Nervoso Central. Dentre os comprometimentos ocasionados pela Síndrome, Wheeler (2018) ressalta que as crianças terão algum nível de comprometimento cognitivo, o que irá exigir um suporte educacional e social que atenda a essas especificidades. Espera-se, ainda, que haja nelas uma severa dificuldade no que concerne à capacidade de compreender e produzir linguagem. Crianças com a SCVZ possuem atrasos no desenvolvimento motor, muitas não são capazes de rolar, sentar, ou, em alguns casos, manter o controle da própria cabeça. Alterações sociais, emocionais e comportamentais também são esperadas a longo prazo (WHEELER, 2018).

Ressalta-se ainda que, graças a programas de estimulação precoce, as crianças com a SCVZ têm obtido avanços nos aspectos sensoriais, motores e cognitivos. Nos primeiros 3 anos de vida o sistema neurológico está sensível às boas influências externas, pois existem as chamadas "janelas de oportunidades": são os períodos críticos de neurodesenvolvimento, onde determinadas áreas do cérebro estão mais suscetíveis para receber influências do ambiente e modificar-se em função dessas influências (VILLACHANLYRA; ALMEIDA, 2018). Além dos centros especializados para estimulação destas crianças, a escola também constitui um importante espaço de estimulação. Portanto, é de suma importância que a inclusão escolar de crianças com a SCVZ seja bem planejada pela escola, a fim de que os avanços no desenvolvimento destas crianças sejam cada vez mais expressivos.

\section{A Inclusão de crianças com a Síndrome Congênita do Vírus Zika na Educação Infantil}

No que concerne à legislação vigente, a Lei no 8.069/90 no Art. 54, inciso III, determina "o atendimento educacional especializado aos portadores de deficiência, preferencialmente na rede regular de ensino" (BRASIL, 2010a, p. 31). Consta na Declaração de Salamanca que "as escolas terão de encontrar formas de educar com sucesso as crianças, incluindo aquelas que apresentam incapacidades graves" (UNESCO, 1994, p. 06).

Dentre os marcos legais que asseguram os direitos das pessoas com deficiência, convém mencionar a LEI № 13.146, nomeada de Lei Brasileira de Inclusão da Pessoa com Deficiência. No que concerne aos direitos à educação, no Capítulo IV Art. 27 a referida Lei, assegura que: 
http://dx.doi.org/10.5902/1984686X36360

A educação constitui direito da pessoa com deficiência, assegurado sistema educacional inclusivo em todos os níveis e aprendizado ao longo de toda a vida, de forma a alcançar o máximo desenvolvimento possível de seus talentos e habilidades físicas, sensoriais, intelectuais e sociais, segundo suas características, interesses e necessidades de aprendizagem (BRASIL, 2015, p. 34).

Contudo, é pertinente considerar que os documentos que respaldam o direito dos estudantes à educação inclusiva têm avançado no país, de maneira mais efetiva em relação à ampliação do acesso, mas não na melhoria da qualidade dos processos educacionais inclusivos (RECIFE, 2015). Isso porque, um sistema educacional só pode ser considerado inclusivo quando abrange a definição ampla desse conceito, ou seja, reconhece que todas as crianças podem aprender, e para isso, é necessário que haja estrutura física adaptada, profissionais habilitados e metodologias de ensino que sejam capazes de atender as especificidades individuais.

A real inclusão permite ao aluno sentir-se pertencente à escola e ao grupo, e a escola sente-se responsável pelo aluno, de modo a comprometer-se em desenvolver uma pedagogia capaz de educar a todos, inclusive aqueles com múltiplas deficiências. Para tanto, as escolas precisam considerar a diferença não somente como um desafio, mas como uma oportunidade para a criação de novas situações de aprendizagem, que venham a contribuir para o desenvolvimento de todos os discentes (SANCHES; TEODORO, 2006). Sabendo-se da importância da escola enquanto um espaço de socialização e promoção de desenvolvimento, é fundamental que a inclusão ocorra já na Educação Infantil.

A Educação Infantil constitui a primeira etapa da Educação Básica e, a partir da Emenda Constitucional n59/2009, passa a ser obrigatória para as crianças de 4 e 5 anos, e opcional para aquelas de 0 a 4 anos em ambientes de creches. Os eixos estruturantes das práticas pedagógicas da Educação Infantil são as interações e a brincadeira, pois essas oportunizam às crianças aprenderem por meio das interações entre pares e com adultos, e com isso, o desenvolvimento e a socialização são oportunizados (BRASIL, 2018b).

Assim, quanto mais cedo a inclusão escolar acontece, maiores serão os benefícios. De acordo com Mendes (2016, p. 252) “com o suporte necessário e apropriado, as crianças pequenas com necessidades educacionais especiais podem tanto adquirir habilidades complexas quanto participar com sucesso de ambientes inclusivos". É importante reiterar que a inclusão na Educação Infantil propicia ainda o aprendizado ao respeito às 
diversidades, onde o convívio entre crianças com desenvolvimento típico e atípico auxilia a minimizar a incidência da discriminação e preconceito.

Entretanto, a inclusão de crianças com deficiência na Educação Infantil constitui um cenário de desafios a serem enfrentados pelos educadores, que relatam a insuficiência de treinamento que os subsidie quanto aos cuidados necessários, e as estratégias capazes de promover o desenvolvimento desses discentes, havendo ainda queixas quanto ao baixo salário, sobrecarga de trabalho e carência de suporte familiar da criança (MENDES, 2016). Ainda de acordo com Mendes (2016, p. 259) "no caso de crianças com limitações desenvolvimentais mais severas, se observa um desconhecimento total do educador sobre como proporcionar melhores condições para atender as necessidades dessas crianças".

Diante do exposto, é possível presumir que é de suma importância que instituições de Educação Infantil recebam um maior suporte, e haja uma melhoria na estrutura física das escolas, bem como um maior investimento em formações continuadas que instrumentalize os docentes para lidar com crianças com deficiência, inclusive aquelas com múltiplos comprometimentos, tais como as com a Síndrome Congênita do Vírus Zika. Ainda são incipientes os saberes acerca da inserção de crianças com a Síndrome Congênita no cenário escolar, porém em 2016 foi lançada a Nota Técnica № 25 (BRASIL, 2016), que dispõem sobre a escolarização das crianças com microcefalia. $O$ referido documento diz que:

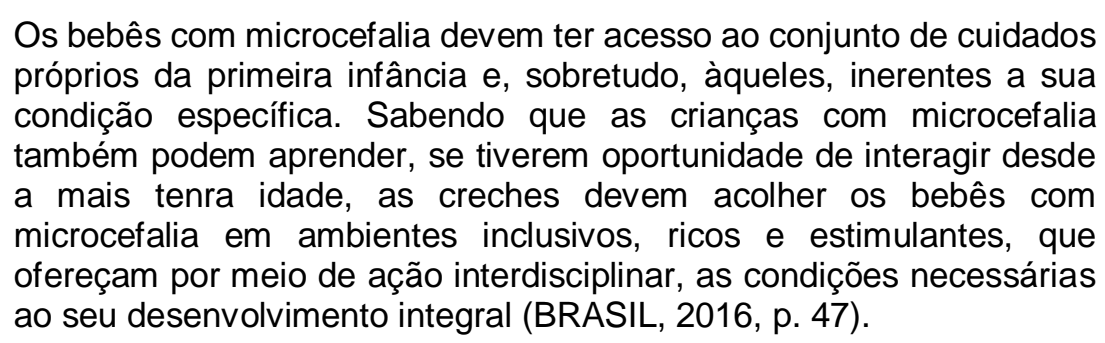

Em função dos comprometimentos ocasionados pela Síndrome, as crianças precisarão de um suporte especializado. Conforme reitera Da Silva et al. (2018) é importante que os professores e cuidadores tenham contato com profissionais de saúde que ofertem informações quanto a importância de estimular a postura correta da criança, podendo para isso utilizar instrumentos como calça de posicionamento, cadeira de rodas, cadeira de posicionamento para o chão, mesa recortada, e também como segurar a criança no colo da maneira adequada e transportá-la com o máximo de segurança. Sobre o brincar, no momento do recreio, devem ser analisados quais tipos de brincadeiras poderão ser 
desenvolvidas com as crianças com SCVZ, entretanto, de forma alguma isso implica dizer que elas não deverão participar das brincadeiras ofertadas, ao contrário, deve-se formular estratégias de modo que a brincadeira se adeque as limitações da criança.

Dado o elevado número de casos da Síndrome, é possível considerar que instituições de ensino no Brasil todo irão receber essa nova demanda de discentes. Com isso, é necessário que haja professores especializados em Educação Inclusiva, espaços físicos adaptados e uma série de recursos que garantam em termos educacionais todo o desenvolvimento possível. Lançamos então algumas questões que nos parecem pertinentes por se tratarem de um agente importante na Educação Infantil: como os/as professores/as imaginam sua intervenção para crianças com a Síndrome Congênita do Vírus Zika? O que sabem sobre a Síndrome e seus impactos sobre o desenvolvimento humano? Como eles/elas imaginam que devem planejar uma aula e quais as estratégias didáticas que consideram adequadas para atender as especificidades das crianças com a SCVZ?

\section{Imaginação como caminho investigativo}

Neste estudo a imaginação será tomada como um processo cognitivo capaz de nos auxiliar a entender como professores prospectam uma situação futura. Em estudos recentes, é conceituada como um processo que permite que seres humanos, em sua constante direcionalidade ao futuro, lidem com incertezas e mudanças que um futuro imprevisível pode trazer, ao mesmo tempo em que, no presente, nos integramos ao passado (TATEO, 2015, 2017; VALSINER, 2014). Mais especificamente consideraremos a definição de imaginação proposta por Tateo (2015), segunda a qual é uma função psicológica "dedicada à manipulação de um conjunto complexo de signos icônicos e linguísticos" (p.1, tradução nossa). Por esta razão, o desenho do estudo e a proposta analítica que seguem à luz desta compreensão (por exemplo, BATISTA, 2019; CARVALHO, 2019), buscam propor o caminho de significação construído pelas participantes em relação com a pesquisadora.

\section{O estudo: aspectos metodológicos}

Participaram do estudo duas professoras de Educação Infantil que atuam na rede pública de ensino de uma Escola de Referência em Educação Especial, situada em um município da Mesorregião da Mata de Pernambuco. A fim de manter o sigilo das participantes do estudo, bem como da instituição que sediou a pesquisa, as docentes 
receberam o codinome de Íris e Dália, e a instituição de ensino será chamada de Escola Recanto do Saber.

Íris tinha 45 anos na época em que a pesquisa foi desenvolvida (no ano de 2018). Ela é pedagoga e pós-graduada em Psicopedagogia Institucional; Educação Especial e Práticas Inclusivas; e Psicopedagogia Clínica. Em 2016 concluiu o Mestrado e teve como tema de sua dissertação o Atendimento Educacional Especializado. Atua como professora há 17 anos e há 3 anos trabalha em turmas de Educação Infantil. A professora Dália de 48 anos é graduada em Letras e em Psicologia, Pós-graduada em Psicomotricidade Relacional, atua há 23 anos como docente, e há 3 anos leciona em turmas de Educação Infantil.

A pesquisa foi desenvolvida em uma escola que é referência municipal no Ensino Fundamental I e recebe uma considerável demanda de alunos com deficiência: no ano de 2018 havia 79 crianças com deficiência matriculadas. Também é considerada como escola de referência no município em Educação Especial. Essa instituição fica localizada na Mesorregião da Mata Pernambucana, em município situado a $48 \mathrm{~km}$ de Recife-PE. Na Escola Recanto do Saber, no ano de 2018, 1.294 alunos estavam matriculados nas seguintes modalidades de ensino: Educação Infantil, Educação Especial e Ensino Fundamental I, distribuídos nos turnos matutino e vespertino. A escola contava com um total de 121 funcionários.

$\mathrm{Na}$ estrutura física foram observados alguns problemas, tais como: as salas de aula não possuíam portas, alguns banheiros estavam quebrados e, embora seja uma escola de referência em Educação Especial, das 25 salas de aula existentes, apenas 6 são acessíveis para alunos com mobilidade reduzida; as demais possuem degrau, o que dificulta o acesso para aqueles que possuem limitações físicas e fazem uso de cadeira de rodas ou muletas. Até o término da pesquisa, os profissionais da escola não haviam participado de cursos, palestras ou formações continuadas que os instrumentalizassem para a docência a crianças com a Síndrome Congênita do Vírus Zika. As duas professoras entrevistadas, atuantes na Educação Infantil, lecionavam para 20 alunos na faixa etária de 04 anos, e não contavam com a ajuda de um professor auxiliar. Esses fatores do contexto de trabalho das participantes nos auxiliam na compreensão de como elas imaginam a docência para crianças com a SCVZ. 
O planejamento metodológico incluía a realização de 3 entrevistas semiestruturadas com as participantes. Cada entrevista teve como objetivo: 1) investigar acerca das informações que as docentes tinham sobre a SCVZ e suas experiências anteriores quanto a lecionar para crianças com deficiência. Nessa etapa, iniciou-se ainda a sondagem do que as participantes imaginavam acerca da docência a crianças com a SCVZ; foi solicitado nesta ocasião que trouxessem ao encontro seguinte um plano de aula considerando a inclusão de crianças com a SCVZ em sua sala de aula; 2) investigar sobre os desafios e possibilidades imaginados para a docência a crianças com a SCVZ e discutir sobre como foi pensada a aula planejada pelas docentes considerando a inclusão desse público e 3) discutir acerca das estratégias didáticas pensadas pelas participantes como eficazes na docência de crianças com a SCVZ.

O estudo foi planejado em uma sequência de encontros para oportunizar um processo de reflexão às docentes sobre o tema, face o ineditismo da Síndrome. Embora o desenho de 3 encontros tenha sido elaborado, Dália participou apenas de duas entrevistas, porque alegou não ter disponibilidade para um terceiro encontro. A segunda entrevista de Dália incluiu os objetivos previstos para a terceira entrevista. As entrevistas ocorreram na própria Escola Recanto do Saber, em sala de aula, sem a presença de estudantes. Foi estabelecido um intervalo de ao menos uma semana entre as entrevistas, mas a definição do encontro era feita de acordo com a disponibilidade das docentes. A construção e análise dos dados seguiram os pressupostos de uma pesquisa qualitativa, mediante o reconhecimento de que os objetos de investigação são únicos e contingentes ao contexto. Para tanto, as entrevistas realizadas com as duas participantes não se destinaram a uma extração de informações, e sim, foram uma ferramenta interativa que adquiriu sentido a partir da inter-relação entre pesquisador e participante (MADUREIRA; BRANCO, 2001).

\section{Resultados e discussão}

O material deste estudo inclui o resultado de 5 entrevistas realizadas com as duas participantes. No processo analítico se buscou identificar as manifestações discursivas em que as docentes se reportavam aos pontos que motivaram desta investigação: seus conhecimentos sobre a síndrome e o que imaginavam sobre a aula a crianças diagnosticadas com a síndrome. Ou seja, como seria a aula, que estratégias seriam utilizadas por elas, dificuldades e potencialidades da escola e das professoras para o exercício da docência nestes casos. Estes pontos foram considerados importantes por nos 
esclarecerem sobre formação para a prática docente na particular situação de lecionarem a crianças cuja sintomatologia ainda é pouco conhecida no contexto escolar. Deste modo, a partir do trabalho de análise das entrevistas por duas investigadoras do tema imaginação, foram selecionados fragmentos das entrevistas que traziam preocupações comuns a ambas professoras. Foram então propostos os seguintes temas: 1) preparo da escola para a inclusão de crianças com a SCVZ; 2) desafios da inclusão escolar em função das condições na estrutura física da instituição; 3) Sentimentos das docentes sobre o lecionar para crianças com a SCVZ; 4) estratégias pensadas para a inclusão de crianças com a SCVZ; 5) possibilidades de ação para lecionar conteúdos específicos às crianças com a SCVZ; e 6) ausência de suporte ao docente no processo de inclusão à crianças com a SCVZ.

Quadro1- Fragmentos de entrevistas elaborados por Íris e Dália a respeito de temas referentes ao ensino a crianças com a SCVZ.

\begin{tabular}{|c|c|c|}
\hline Temáticas abordadas & Íris & Dália \\
\hline $\begin{array}{l}\text { Preparo da escola para a } \\
\text { inclusão de crianças com a } \\
\text { SCVZ. }\end{array}$ & 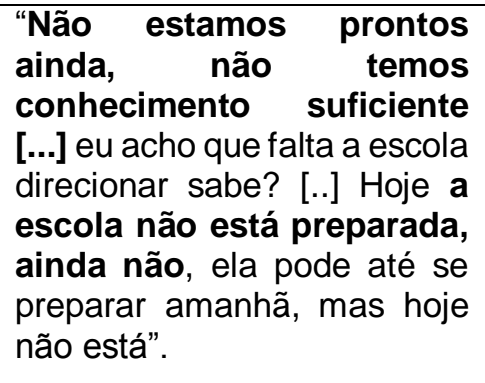 & $\begin{array}{l}\text { "Eu respondo a você com } \\
\text { todas as letras, a prefeitura } \\
\text { não está pronta para } \\
\text { receber, por que precisa de } \\
\text { algumas coisas que favoreça } \\
\text { a essas crianças". }\end{array}$ \\
\hline $\begin{array}{l}\text { Desafios da inclusão escolar } \\
\text { em função das condições na } \\
\text { estrutura física da instituição }\end{array}$ & $\begin{array}{l}\text { "Se eu tiver um aluno } \\
\text { cadeirante, olha pra minha } \\
\text { sala, qual a acessibilidade } \\
\text { que ela tem? Ela tem a } \\
\text { largura para passar uma } \\
\text { cadeira de rodas, mas ela } \\
\text { não tem acessibilidade [...] } \\
\text { E veja bem, nós receberemos } \\
\text { essas crianças ok, só que } \\
\text { com qual estrutura? A gente } \\
\text { tem que ter isso também, } \\
\text { estrutura de tudo, não } \\
\text { adianta dizer, ah a minha } \\
\text { escola é inclusiva de quê, só } \\
\text { da boca pra fora? Tem que } \\
\text { ter também um apoio". }\end{array}$ & $\begin{array}{l}\text { "Aqui o que eu acho pra mim } \\
\text { o principal, que me dificulta } \\
\text { a inclusão está no próprio } \\
\text { ambiente, uma educação } \\
\text { infantil que o piso não } \\
\text { favorece pra gente estar no } \\
\text { chão, pra gente rolar, pra } \\
\text { gente brincar. O espaço em } \\
\text { si, quando chove vaza água } \\
\text { aqui na sala, recursos a } \\
\text { gente não tem, a gente não } \\
\text { tem pátio de recreação, a } \\
\text { gente não tem nada que diga } \\
\text { assim: pronto isso aqui é uma } \\
\text { educação infantil, entendeu?" }\end{array}$ \\
\hline $\begin{array}{l}\text { Sentimentos das docentes } \\
\text { sobre o lecionar para } \\
\text { crianças com a SCVZ }\end{array}$ & $\begin{array}{l}\text { "É um sentimento que vem } \\
\text { medo, vem dúvida, vem } \\
\text { insegurança, eu acho que o } \\
\text { último que vai vir é }\end{array}$ & $\begin{array}{l}\text { "Ai eu me pergunto, toda vez } \\
\text { quando escuto alguma coisa, } \\
\text { se eu receber ano que vem, } \\
\text { elas com } 4 \text { anos na minha }\end{array}$ \\
\hline
\end{tabular}




\begin{tabular}{|c|c|c|}
\hline & $\begin{array}{l}\text { segurança, por que é novo } \\
\text { [...] Dependendo da situação } \\
\text { com certeza tem que ter o } \\
\text { cuidador, por que você não } \\
\text { vai conseguir trabalhar só, o } \\
\text { professor não vai dar conta } \\
\text { sozinho, e principalmente se } \\
\text { a criança for uma criança que } \\
\text { não anda, ou uma que não } \\
\text { fale, ou uma que não veja, e } \\
\text { aí como é que a gente vai } \\
\text { fazer?" }\end{array}$ & $\begin{array}{l}\text { sala, onde eu vou sentar? } \\
\text { Onde eu vou colocar essa } \\
\text { criança? Se essa criança tiver } \\
\text { uma convulsão como eu vou } \\
\text { agir com essa criança? Qual é } \\
\text { a cuidadora que eu vou poder } \\
\text { estar com } 18 \text { alunos dentro de } \\
\text { uma sala e com essa criança } \\
\text { dentro da minha sala. Ela vai } \\
\text { poder levar uma pancada, ela } \\
\text { vai poder ter alguma coisa, se } \\
\text { ela quiser correr como eu vou } \\
\text { agir? Então eu venho agora } \\
\text { com essas angústias por } \\
\text { que eu sei que o meu } \\
\text { ambiente não vai favorecer } \\
\text { pra ela, então o meu primeiro } \\
\text { ponto é: como eu vou agir } \\
\text { com ela hoje, com o pouco } \\
\text { que eu tenho?" }\end{array}$ \\
\hline $\begin{array}{l}\text { Estratégias pensadas para a } \\
\text { inclusão de crianças com a } \\
\text { SCVZ }\end{array}$ & $\begin{array}{l}\text { "Olhe, os desafios são } \\
\text { muitos, mas primeiro eu } \\
\text { acredito que é preciso } \\
\text { trabalhar nos demais a } \\
\text { aceitação dessa criança. E } \\
\text { trabalhar a aceitação da } \\
\text { própria família também [...]. } \\
\text { Vamos ter que nos adaptar } \\
\text { para atender essa criança, } \\
\text { por que ela ficar sozinha lá no } \\
\text { cantinho sem desenvolver, } \\
\text { não é inclusão, é exclusão". }\end{array}$ & $\begin{array}{l}\text { "Para mim ter inclusão na } \\
\text { sala, é poder trabalhar com } \\
\text { o grupo, mas ela dentro } \\
\text { desse grupo, de forma } \\
\text { nenhuma excluí-la, então } \\
\text { coloca-la dentro desse } \\
\text { grupo, pra depois eu tratá-la } \\
\text { individualmente, enquanto } \\
\text { esse grupo faz alguma } \\
\text { coisa, eu vou poder } \\
\text { estimulá-la, por que } \\
\text { microcefalia vai sempre } \\
\text { pedir isso, me estimule, me } \\
\text { estimule, me estimule, o } \\
\text { máximo que você me } \\
\text { estimular pra que eu possa } \\
\text { desenvolver". }\end{array}$ \\
\hline $\begin{array}{l}\text { Possiblidades de ação para } \\
\text { lecionar conteúdos } \\
\text { específicos às crianças com } \\
\text { a SCVZ }\end{array}$ & $\begin{array}{l}\text { "Eu sei que eu enquanto ser } \\
\text { humano preciso me preparar, } \\
\text { estudar sobre o assunto, } \\
\text { conhecer as atividades que } \\
\text { eu possa trabalhar com essa } \\
\text { criança, conhecer as } \\
\text { atividades para adaptar [...] } \\
\text { Será preciso trabalhar com } \\
\text { materiais concretos e } \\
\text { materiais de sucata } \\
\text { também são riquíssimos } \\
\text { [...] Digamos que eu fosse } \\
\text { trabalhar hoje o numeral 3, } \\
\text { quanto mais brilho e } \\
\text { colorido pra essa realidade } \\
\text { melhor, posso fazer o } \\
\text { numeral em alto relevo, no } \\
\text { guache ou com algodão [...] } \\
\text { Com a criança com }\end{array}$ & $\begin{array}{l}\text { "Quando essa criança chegar, } \\
\text { o primeiro passo que eu } \\
\text { preciso dar é conhecê-la, } \\
\text { depois que eu conhecê-la, } \\
\text { depois que eu souber o que é } \\
\text { que ela pode me apresentar, } \\
\text { eu vou ter que descobrir } \\
\text { também o que eu posso } \\
\text { apresentar pra ela e de que } \\
\text { forma né? [...] Com a } \\
\text { microcefalia precisa ser } \\
\text { uma coisa mais concreta, } \\
\text { que ela possa pegar, que } \\
\text { ela possa sentir, precisa ser } \\
\text { colorido [...] Então eu } \\
\text { pensei em trabalhar as } \\
\text { formas geométricas com } \\
\text { ela a partir dos blocos } \\
\text { lógicos, feitos de madeira, }\end{array}$ \\
\hline
\end{tabular}




\begin{tabular}{|c|c|c|}
\hline & $\begin{array}{l}\text { microcefalia tem que ter } \\
\text { muito material didático [...] } \mathrm{O} \\
\text { brincar é muito importante, a } \\
\text { professora vai ter que ensinar } \\
\text { brincando". }\end{array}$ & $\begin{array}{l}\text { onde ela vai estar em } \\
\text { contato, vai pegar. Tem } \\
\text { blocos que são finos, e blocos } \\
\text { mais grossos, então além da } \\
\text { forma a gente trabalha a } \\
\text { espessura também". }\end{array}$ \\
\hline $\begin{array}{l}\text { Ausência de suporte ao } \\
\text { docente no processo de } \\
\text { inclusão à crianças com a } \\
\text { SCVZ }\end{array}$ & $\begin{array}{l}\text { "Eu tô pra receber, mas eu já } \\
\text { sei que não tenho apoio, e } \\
\text { a escola sabe, o governo } \\
\text { sabe, mas sozinha eu não } \\
\text { dou conta, sozinha nenhum } \\
\text { professor dá conta, não é que } \\
\text { é incapaz, não é isso, é que } \\
\text { tem que ter o apoio, essa } \\
\text { criança vai precisar muito de } \\
\text { alguém, ela vai ser muito } \\
\text { dependente". }\end{array}$ & $\begin{array}{l}\text { "A microcefalia pra mim vai } \\
\text { ser o desafio do estudo e eu } \\
\text { sei que eu vou ter que } \\
\text { garimpar isso sozinha, por } \\
\text { que não vai chegar ninguém } \\
\text { pra me dizer não". }\end{array}$ \\
\hline
\end{tabular}

A partir dos fragmentos de entrevistas exibidos no quadro acima podemos fazer algumas reflexões acerca dos desafios e possibilidades da docência a crianças com a SCVZ, que foram indicados pelas participantes do estudo. Supomos que o fato das docentes partilharem do mesmo contexto de trabalho ao passo que vivenciam desafios semelhantes, gera aproximações quanto ao que imaginam sobre a possível docência a crianças com a SCVZ.

O contexto é compreendido por nós como um espaço dialógico onde as atividades mentais humanas se desenvolvem, e as pessoas constroem sentidos em relação a tudo que thes circunda (GAMSAKHURDIA, 2018). Assim, a escola ser referência em Educação Especial no município é uma informação do contexto das participantes que nos permite compreender o porquê de elas considerarem possível receber esses discentes em 2019. Além disso, no município onde a escola Recanto do Saber se localiza há pelo menos 13 casos de crianças com a SCVZ (SOUZA, 2017).

No primeiro e segundo eixos temáticos exibidos no quadro 1, vê-se que as docentes consideram que a Escola Recanto do Saber não está apta para incluir alunos com a SCVZ, tanto porquê os profissionais não têm recebido preparo técnico que os instrumentalize para a docência desse público, quanto pelas más condições na estrutura física da escola; embora seja tida como de referência em Educação Especial, não possui estrutura física 
adaptada, nem mesmo um parque ou qualquer espaço de lazer que propicie a interação e o desenvolvimento dos alunos através do brincar.

Essa realidade não está circunscrita à escola onde a pesquisa foi desenvolvida.O censo escolar aponta que, em 2018 , pelo menos $50 \%$ das escolas públicas brasileiras que ofereceram a modalidade de Educação Infantil, não dispunham de estrutura adequada por não possuírem parques e área verde para lazer. O mais surpreendente é que apenas $26,1 \%$ das creches públicas no Brasil possuem vias acessíveis para crianças com mobilidade reduzida (MARTINS, 2018). Desse modo, o modelo de escolas que temos atualmente está aquém de suprir as necessidades das crianças, e menos ainda daquelas com múltiplos comprometimentos.

Nas palavras de Silva et al. (2018, p. 34) "o que dificulta o processo de inclusão escolar é a falta de preparo, capacitação dos profissionais e a falta de estrutura das escolas". A fala das participantes tem elementos deste sentido compartilhado por estudiosos, já que o contexto de problemas com a estrutura física da escola e a falta de recursos, constituem desafios para que a inclusão se efetive conforme recomenda a legislação.

Outra observação a ser feita diz respeito à insegurança das docentes com relação a como assistir adequadamente a criança com a SCVZ no caso dela possuir múltiplas deficiências, e como proceder caso ela venha a ter alguma intercorrência em sala de aula. Convém frisar que Íris possui conhecimento em Educação Inclusiva em virtude das pósgraduações que cursou, e Dália, além de psicóloga, já há três anos consecutivos tem, em sua sala de aula, crianças com paralisia cerebral e autismo. Porém, dado o caráter inédito da SCVZ e o padrão de múltiplas deficiências, a fala das docentes aponta para a antecipação de uma experiência imaginada caracterizada por uma série de tensões relativas à docência a esse público.

A partir dessa observação, julgamos que seria de suma importância que as formações continuadas sobre a SCVZ fossem feitas em parceria com os profissionais de saúde, pois os psicólogos, fonoaudiólogos, fisioterapeutas e terapeutas ocupacionais poderiam instruir os profissionais da educação acerca das melhores estratégias de cuidado a serem empreendidos a esses discentes. É preciso considerar que algumas crianças tem disfagia, assim os alimentos e as técnicas de alimentação devem ser pensadas para evitar engasgos. 
Uma das inquietações imaginadas por Dália refere-se à possibilidade de a criança ter uma crise convulsiva na escola. Nesses casos, os profissionais de saúde podem orientar que o professor deite a criança de lado para que evite engasgos, não contenha a criança e espere entre 2 a 10 minutos até que a crise passe. No caso de convulsões prolongadas ou a criança apresente cianose (fique com a pele roxa), ela deve ser encaminhada a um serviço de saúde (VILLACHAN-LYRA, ALMEIDA, 2018). Receber essas instruções pode deixar as docentes menos apreensivas quanto a como proceder nesses casos e a antecipação do futuro ser então feita com base em informações precisas que efetivamente auxiliem no cuidado aos discentes. Até o momento em que a pesquisa foi finalizada, Dália e Íris afirmaram não ter tido acesso a essa informações, ou a qualquer conhecimento mais específico sobre a Síndrome.

Felizmente, as docentes parecem acreditar que a inclusão de crianças com a SCVZ é possível. Elas relatam os desafios, porém, dizem que imaginam trabalhar o processo de inclusão através da inserção da criança nas brincadeiras, e mediante um trabalho de aceitação, que deve envolver a família da criança, os profissionais da escola e demais alunos. Dália enfatiza a importância da estimulação para que a criança desenvolva, e conforme mencionado anteriormente, essa estimulação não é circunscrita exclusivamente às terapias desenvolvidas pelos profissionais de saúde, mas acontecem, sobretudo, na escola onde através de jogos, brincadeiras e contação de histórias, as crianças têm promovido seu desenvolvimento motor, cognitivo e sensorial.

Quando questionadas sobre as estratégias didáticas que imaginam desenvolver para a docência de crianças com a SCVZ, tanto Íris quanto Dália enfatizam a importância de utilizar objetos concretos, coloridos, com texturas, e que possam ser tocados pela criança. Íris enfatiza ainda a importância de conhecer sobre a Síndrome a fim de aprender quais materiais poderá confeccionar para trabalhar com a criança de modo a atender suas especificidades.

As estratégias imaginadas pelas docentes são úteis para crianças com a SCVZ, já que algumas podem ter cegueira ou baixa visão. Nesta mesma direção tem-se os profissionais de saúde, que recomendam o uso de objetos coloridos, grandes e de diferentes texturas (MARÇAL; OLIVEIRA, 2017). Supomos que as profissionais acreditam na eficácia dessas estratégias porque as próprias Diretrizes Curriculares Nacionais de Educação Infantil preconizam que os eixos estruturantes das práticas pedagógicas dessa 
etapa de ensino são as interações e a brincadeira, que explorem os movimentos, gestos, sons, formas, texturas e cores (BRASIL, 2010b).

O Guia de Estimulação para crianças com Síndrome do Vírus Zika, desenvolvido por Marçal e Oliveira (2017), exibe as atividades a serem empreendidas na estimulação de crianças com a SCVZ. Os autores apresentam as estratégias para a estimulação multissensorial, incluindo visão, audição, tato, olfato e paladar. Observou-se que as participantes do estudo enfatizaram apenas a estimulação visual, porém não conseguiram imaginar estratégias capazes de estimular os outros sentidos. O guia instrui ainda quanto as formas de segurar a criança com a Síndrome, bem como aponta para as estratégias de estimulação da linguagem, da motricidade e da socioafetividade, fatores esses que também não foram mencionados pelas docentes.

Isso reitera a importância de cursos e formações continuadas que possam apresentar aos profissionais da educação, além das especificidades da SCVZ, os objetos do dia a dia que podem ser utilizados como instrumentos de estimulação. $O$ Guia de Estimulação mostra como caixas de papelão, bacias, lanternas, chocalhos, rolos, bolas, etc, podem ser importantes aliados para desenvolvimento de crianças com a Síndrome.

Outro aspecto curioso diz respeito a uma transformação no processo de significar a docência a crianças com a SCVZ. Íris e Dália no primeiro momento relatam sentimentos de insegurança, de não saber como proceder diante das especificidades da Síndrome, e apontam os problemas de estrutura física e ausência de recursos, como dificultadores do processo de inclusão. Porém, quando questionadas sobre como fariam para dar aulas considerando a presença da criança com a Síndrome, elas imaginam como trabalhar números (Íris) e formas geométricas (Dália), de modo a atender às especificidades da criança.

Entende-se, assim, que a experiência de imaginar a docência para crianças com a Síndrome promove uma adaptação em meio aos desafios e dúvidas da docência a esse público. Como propõe Tateo (2015), a imaginação é uma função psicológica fundamental que auxilia no gerenciamento das incertezas da vida cotidiana, sendo uma forma específica de adaptação que ocorre por meio da elaboração de significados. Assim, quando as docentes prospectam o futuro, elas começam a ver possibilidades em meio aos desafios, e substituem algumas interrogações por algumas certezas e dizem: "vou trabalhar com o concreto", "com o colorido", "vou buscar conhecer sobre a Síndrome", "vou trabalhar a 
aceitação dessa criança", "vou buscar conhecer a criança", "estudar sobre a Síndrome", etc.

O último eixo temático das entrevistas diz respeito à ausência de suporte para a inclusão de crianças com a SCVZ se efetive com êxito. Quanto a isso Íris diz: "Eu tô pra receber, mas eu já sei que não tenho apoio", já Dália diz: "a microcefalia pra mim vai ser o desafio do estudo e eu sei que eu vou ter que garimpar isso sozinha". A fala das docentes em seu processo de imaginar a atuação junto aos alunos com a SCVZ demonstra sobre elas uma sobrecarga de responsabilidade nesse processo de inclusão escolar. É como se as profissionais tivessem certeza que não poderão contar com o apoio da escola e dos governantes, e tivessem que desenvolver, sozinhas, estratégias de atenção e cuidado a crianças com a SCVZ.

A dificuldade das profissionais em imaginar suportes para suas atuações junto a esses discentes faz pensar sobre a importância de os sistemas educacionais, através dos gestores escolares inclusive, atentarem para a necessidade de fortalecimento de vínculos entre sua equipe. Faz-se mister unir forças em prol da superação dos desafios que venham surgir nesse cenário, assim como da imprescindível atuação do Estado, seja na promoção da capacitação do corpo de funcionários, seja na transformação da estrutura e da equipe de suporte para as diversidades de experiências que cada estudante leve a sala de aula.

Em linhas gerais, observa-se que as docentes consideram desafiadora a docência a crianças com a SCVZ, tanto por se tratar de uma síndrome inédita, quanto pelo contexto da Escola Recanto do Saber não oferecer condições favoráveis para que essa docência seja exitosa. Porém, as participantes imaginam que poderão contribuir para o processo de aprendizagem e desenvolvimento dessas crianças. Isso fica perceptível quando Íris diz que vai estudar, conhecer sobre a Síndrome para poder aprender quais atividades poderão ser desenvolvidas com esses discentes. Nessa direção Dália diz que irá buscar conhecer a criança a fim de saber como poderá apresentar os conteúdos a ela. Nesses dois casos, é possível ver uma disponibilidade em querer ensinar e contribuir para o desenvolvimento desses discentes, porém isso não é o suficiente para que a inclusão se efetive conforme recomenda a legislação.

Para que uma criança com a SCVZ seja incluída, a escola precisa ter espaço físico, mobília e brinquedos adaptados, e então os estudantes possam participar das vivências que ocorram no espaço escolar. A escola precisará ainda dispor do suporte de uma 
cuidadora, como bem sinalizou Íris. Convém ressaltar que o/a cuidador(a) é o cargo de Agente de Apoio ao Estudante com Deficiência, que foi criado em 2015, através de um projeto de lei (autoria do executivo municipal de Recife-PE), e tem por objetivo oferecer garantia de apoio necessário a alunos com deficiências nas instituições escolares. Os cuidadores acompanham a criança com deficiência no dia a dia escolar, e ficam responsáveis por atender suas necessidades básicas, tais como: dar o lanche, levar ao banheiro, auxiliar no processo de inclusão nas brincadeiras, auxiliar as crianças na locomoção, execução de atividades pedagógicas desenvolvidas na escola (FARIAS; VILLACHAN-LYRA, 2018).

É animador saber que as participantes da pesquisa acreditam no desenvolvimento da criança com a SCVZ e se propõem a se esforçar para contribuir para que ele ocorra da melhor maneira possível. Porém, precisamos considerar que o êxito da inclusão se dará mediante a realização de um trabalho em rede, onde saúde, educação e políticas públicas possam se unir em prol da oferta de condições para que as crianças tenham a assistência que lhes é de direito.

\section{Considerações finais}

O presente estudo buscou investigar os desafios e possibilidades da docência a crianças com a Síndrome Congênita do Vírus Zika imaginados por duas professoras atuantes na Educação Infantil da rede pública de ensino. Diante dos resultados obtidos foi possível identificar que o caráter inédito da Síndrome, os problemas na estrutura física da escola, a escassez de recursos didáticos e a ausência de formações continuadas, cursos e palestras sobre a SCVZ, são os principais fatores imaginados pelas participantes como dificultadores do processo de inclusão escolar a esses discentes.

Conforme discutido anteriormente, diante da possibilidade de lecionar para crianças com a SCVZ, as profissionais apontaram alguns desafios e tensões, como por exemplo: o que fazer diante da possibilidade da criança ter múltiplas deficiências ou apresentar crises convulsivas. Porém no movimento de distanciar-se do aqui-agora, ou seja, prospectar-se ao futuro, as profissionais passaram a considerar algumas possibilidades de ação. Imaginaram que para ensinar os numerais (Íris) e as formas geométricas (Dália), precisariam desenvolver recursos pedagógicos concretos, coloridos e com texturas que pudessem ser sentidos pelos alunos com a Síndrome. 
As profissionais enfatizaram ainda a importância de estudar sobre a SCVZ. Reconhecem que precisarão conhecer as especificidades da Síndrome para saber como agir com os discentes. Cabe refletir que, embora as profissionais tenham imaginado algumas estratégias de estimulação, como por exemplo o uso de objetos coloridos e de textura, esses foram pensados com base nas experiências que elas têm na docência a crianças de Educação Infantil com desenvolvimento típico, ou com outra deficiência que não a SCVZ, porém não garantem que serão igualmente eficazes se tratando de alunos com a síndrome em questão. Com isso, julgamos que seria imprescindível que as docentes pudessem tomar conhecimento de estratégias que promovam a estimulação multissensorial, cognitiva, motora e socioafetiva desses discentes, e, para isso, o investimento em formações continuadas em parceria com profissionais da saúde torna-se muito relevante.

Indubitavelmente, discutir a inclusão das crianças com a SCVZ ainda envolve muitos desafios. Ainda não se sabe ao certo sobre as deficiências, o padrão das lesões, as repercussões em outras áreas do organismo, e todo o desenvolvimento desses bebês que nasceram de uma gestação onde a mãe havia sido infectada por Zika. Essas são questões que estão sendo descobertas e discutidas com caráter inédito no mundo todo (BRASIL, 2017). Precisamos conceber que a inclusão escolar de crianças com a SCVZ é um novo capítulo que começa a ser escrito na história da educação brasileira, e é preciso unir forças para que esse seja escrito da maneira mais bela possível.

\section{Referências}

BATISTA,Gessivânia de Moura. Processos imaginativos de educadora quanto à docência a crianças com a Síndrome Congênita do Vírus Zika. Dissertação de Mestrado não publicada, Programa de Pós-graduação em Psicologia Cognitiva, UFPE, 2019.

BRASIL. Lei n. 8.069, de 13 de julho de 1990. Estatuto da criança e do adolescente. 9 ed. Brasília, DF, 2010a. 352p.

BRASIL. Ministério da Educação. Secretaria de Educação Básica. Diretrizes curriculares nacionais para a educação infantil. Brasília, DF, 2010b. 40p.

BRASIL. LEI № 13.146. Lei Brasileira de Inclusão da Pessoa com Deficiência. Brasília, DF, 2015. 59p.

BRASIL. Ministério da Educação. Diretoria de Políticas de Educação Especial. Nota técnica ํo 25/2016. Orientações para o acolhimento dos bebês com microcefalia pela educação infantil. In: BRASIL. A consolidação da inclusão escolar no Brasil. Brasília, DF, 2016. $413 p$. 
BRASIL. Ministério da Saúde. Secretaria de Vigilância em Saúde. Vírus Zika no Brasil: a resposta do SUS. Brasília, DF, 2017. 137p.

BRASIL. Ministério da Saúde. Secretaria de vigilância em saúde. Boletim epidemiológico. V. 49, n. ${ }^{\circ} 29,2018 a .8 p$.

BRASIL. Ministério da Educação. Base Nacional Comum Curricular. Brasília, DF, 2018b. 472p.

CARVALHO, Josene Ferreira. Processos imaginativos de uma paciente com câncer sobre cuidados paliativos. Dissertação de Mestrado não publicada, Programa de Pósgraduação em Psicologia Cognitiva, UFPE, 2019.

DA SILVA, Flávia Calheiros. et al. Capacitação para profissionais de Educação Infantil sobre as necessidades educacionais de crianças com Síndrome Congênita do Vírus Zika e outras alterações neurológicas. Revista Educação. Batatais, v. 8, n. 1, p. 57-71, jan. 2018.

EICKMANN, Sophie Helena. et. al. Síndrome da infecção congênita pelo vírus Zika. Caderno de Saúde Pública. Rio de Janeiro, v. 32, n. 7, p. 1-3, jul. 2016. Disponível em: http://www.scielo.br/pdf/csp/v32n7/1678-4464-csp-32-07-e00047716.pdf. Acesso em: 18 dez 2018.

FARIAS, Mirella Rabelo Almeida; VILLACHAN-LYRA, Pompéia. Crianças com a síndrome congênita do vírus da zika e a entrada na creche: um novo capítulo na educação brasileira.

Revista Inclusiones, [S.I.] v. 5, n. 4, p. 122-147, out. 2018.

GAMSAKHURDIA, Vladimer Lado. Constructive urge for self-presentation-mediating between the past and the future. Integrative Psychology Behavior, Georgia, p. 1-20, out. 2018.

LUZ, Kleber Giovanni; SANTOS, Glauco Igor Viana; VIEIRA, Renta de Magalhães. Febre pelo vírus zika. Epidemiologia e Serviços deSaúde. Brasília, n. 24, v. 4, p. 785-788, out. 2015. Disponível em: http://www.scielo.br/pdf/ress/v24n4/2237-9622-ress-24-0400785.pdf. Acesso em: 15 dez 2018.

MADUREIRA, Ana Flávia do Amaral; BRANCO, Angela Uchôa. A pesquisa qualitativa em psicologia do desenvolvimento: questões epistemológicas e implicações metodológicas. Temas em psicologia. Ribeirão Preto, v. 9, n. 1, p. 63-75, jul. 2001.

MARÇAL, Daniela; OLIVEIRA, Flávia. Guia de estimulação para crianças com a síndrome congênita do vírus zika. Rio de Janeiro, p. 1-33, 2017. Disponível em: https://movimentozika.files.wordpress.com/2017/08/guia-de-estimulaccca7acc83omovimento-zika-versacc83o-online.pdf. Acesso em: 02 dez 2018.

MARTINS, Helena. Censo escolar aponta que escolas públicas ainda têm deficiências de infraestrutura. Agência Brasil. Brasília, DF, 31 de Janeiro de /2018. Disponível em: http://agenciabrasil.ebc.com.br/educacao/noticia/2018-01/censo-aponta-que-escolaspublicas-ainda-tem-deficiencias-de-infraestrutura. Acesso em: 27 dez 2018.

MENDES, Eniceia Gonçalves. Inclusão marco zero: começando pelas creches. São Paulo: Jaqueline\&Marin editores, 2016.

RECIFE, Secretaria de Educação. Educação inclusiva: múltiplos olhares Recife, PE, 2015. 104p. Disponível em: 
http://www.portaldaeducacao.recife.pe.gov.br/sites/default/files/arquivos_informativos_ho me/Educacaolnclusiva.pdf>. Acesso em: 07 dez 2018.

RIBEIRO, Bruno Niemeyer de Freitas. et al. Síndrome congênita pelo vírus Zika e achados de neuroimagem: o que sabemos até o momento? Radiologia Brasileira. São Paulo, v. 50, n. 5, p. 314-322, set. 2017. Disponível em: http://www.scielo.br/pdf/rb/v50n5/pt_01003984-rb-50-05-0314.pdf. Acesso em: 6 dez. 2018.

SANCHES, Isabel; TEODORO, Antônio. Da integração à inclusão escolar: cruzando perspectivas e conceitos. Revista Lusófona de Educação, [S.I.] v. 8, n. 8, p. 63-86, jul. 2006. Disponível em: http://revistas.ulusofona.pt/index.php/rleducacao/article/view/691. Acesso em: 2 dez. 2018.

SILVA, Anderson Felipe Pereira. et al. A educação especial em uma escola municipal de Recife-PE. In: Atena Editora. (Org.). Políticas públicas na educação brasileira: caminhos para a inclusão. Ponta Grossa-PR: Atena Editora, 2018, p. 29-36.

SOUZA, Shirley Emanuely Pontes. Reabilitação para crianças com síndrome congênita do zika vírus: percepção de profissionais de saúde em uma unidade de Vitoria de Santo Antão Pernambuco. Vitória de Santo Antão-PE. [S.I.], 2017. Disponível em: https://repositorio.ufpe.br/bitstream/123456789/24039/1/SOUZA\%2C\%20SHIRLEY\%20E MANUELY\%20PONTES\%20DE.pdf. Acesso em: 1 dez. 2018,

TATEO, Luca. Seeing Imagination as Resistance and Resistance as Imagination. In: CHAUDHARY, Nandita. et al. (Ed.). Resistance in everyday life: Contructing cultural experiences. Springer, 2017, p. 233-245.

TATEO, Luca. Just na Illusion? Imagination as higher mental function. Journal of Psychology \& Psychotherapy. New York, v. 5, n. 6, p. 1-6, 2015. Disponível em: https://www.omicsonline.org/open-access/just-an-illusion-imagination-as-higher-mentalfunction-2161-0487-1000216.pdf. Acesso em: 12 dez. 2018.

UNESCO. Declaração de Salamanca e enquadramento de acção: necessidades educativas especiais. Salamanca-Espanha. 1994. 49p. Disponível em: http://redeinclusao.pt/media/fl_9.pdf>. Acesso em: 12 dez 2018.

VALSINER, Jaan. An invitation cultural to cultural psychology. Londres: Sage, 2014.

VARGAS, Alexander. et al. Características dos primeiros casos de microcefalia possivelmente relacionados ao vírus Zika notificados na Região Metropolitana de Recife, Pernambuco. Epidemiologia eServiços de Saúde. Brasília, n. 25, v. 4, p. 691-700, out. 2016. Disponível em: http://www.scielo.br/pdf/ress/v25n4/2237-9622-ressS1679_49742016000400003.pdf. Acesso em: 13 dez. 2018

VILLACHAN-LYRA, Pompéia; ALMEIDA, Eliana. Síndrome congênita do zika vírus, microcefalia e outras alterações do neurodesenvolvimento: um olhar para a educação. Revista Inclusiones. [S.I.] v. 5, n, 4, p. 77-103, out. 2018.

WHEELER, Anne C. Development of Infants With Congenital Zika Syndrome: What Do We Know and What Can We Expect? Pediatrics. [S.I.] v. 141, n. 2, p. 154-160, fev. 2018. Disponível em: <http://pediatrics.aappublications.org/content/141/Supplement_2/S154>. Acesso em: 19 dez. 2018. 


\section{Correspondência}

Gessivânia de Moura Batista - Universidade Federal de Pernambuco.Rua: Av. Prof. Moraes Rego, 1235 - Cidade Universitária. CEP: 50670-901. Recife, Pernambuco, Brasil.

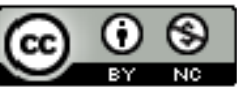

This work is licensed under a Creative Commons Attribution-NonCommercial 4.0 International (CC BY-NC 4.0) 